\title{
IS CEREBELLAR GRANULE CELL MIGRATION REGULATED BY AN INTERNAL CLOCK? ${ }^{1}$
}

\author{
E. TRENKNER, ${ }^{2}$ D. SMITH, ${ }^{3}$ AND N. SEGIL ${ }^{4}$
}

Department of Pharmacology, New York University Medical Center, New York, New York 10016

Received March 14, 1984; Revised May 29, 1984; Accepted May 30, 1984

\begin{abstract}
We have studied the time course of migratory behavior of cerebellar granule cells in the microwell tissue culture system. $\left[{ }^{3} \mathrm{H}\right]$ Thymidine served as a marker for particular granule cell generations. When cultured $4 \mathrm{hr}$ after $\left[{ }^{3} \mathrm{H}\right]$ thymidine injection for 6 days in microwell cultures, labeled granule cells were seen to migrate along fiber bundles expanding between reaggregates called "cables" for 3 to 4 days. After 5 and 6 days in vitro the percentage of labeled non-migrating cells found in clusters in reaggregates and on cables increased considerably. Whereas unlabeled cells continued to migrate. Comparable results were obtained when granule cells developed in vivo for various times after label and their developmental state was determined in vitro. Cells from cerebellar populations labeled 1 to 4 days before culture maintained their ability to migrate in vitro, even after granule cells had entered the internal granule cell layer. In contrast, the percentage of migrating cells labeled 5 and 6 days before culture was reduced significantly. The results suggest that the time span of granule cell migration is predetermined intrinsically rather than by external signals.
\end{abstract}

Cells in the developing central nervous system (CNS) are formed in specialized germinal zones and obtain their final position through active migration. The migratory process is thought to be governed in part by genetically and epigenetically defined sequences of signals which are interpreted by migrating cells. This study attempts to determine the developmentally important signals for the timing of cerebellar granule cell maturation as defined by cell migratory behavior and interactions with other cells in vitro.

During the initial period of proliferation, all external granule cells (EGCs) appear to be engaged in DNA synthesis and mitosis. In the cerebellum pulse labeling with $\left[{ }^{3} \mathrm{H}\right]$ thymidine has been used to determine the birth dates of cerebellar neurons and to describe the period of cell proliferation of particular granule cell generations (Miale and Sidman, 1961; Fujita, 1964, 1967; Fujita et al., 1966; Altman et al., 1982). In the past decade, Rakic and others (Rakic, 1971, 1974, 1978, 1981; Caviness and Rakic, 1978; Levitt and Rakic, 1980) have established that, in the CNS, immature migrating neurons are closely associated with radial glia cell processes. Time of origin and route of

${ }^{1}$ We would like to thank Drs. L. A. Greene, S. H. Green, M. E. Hatten, C. Jaeger, C. A. Mason, P. Sajovic, and M. L. Shelanski for their discussion and reading of this manuscript. We wish to thank Dr. R. L. Sidman for his interest and support at the beginning of this study. This work was supported by National Institute of Health Grant NS 16070-02 to E. T.

${ }^{2}$ To whom correspondence should be addressed.

${ }^{3}$ Present address: Department of Pathology, Brigam and Women's Hospital, Boston, MA 02115.

${ }^{4}$ Present address: Department of Biology, 118 Fairchild, Columbia University, New York, NY 10027. migration of immature granule cell neurons have been described in a large number of studies (Ramón y Cajal, 1929; Miale and Sidman, 1961; Fujita, 1964, 1967; Fujita et al., 1966; Altman, 1982). After their last mitosis granule cells move into a postmitotic zone where they wait for 21 to $24 \mathrm{hr}$ and then migrate into deeper layers of the cerebellar cortex. The migration of one generation of EGCs from the external granule cell layer (EGL) into the internal granula cell layer (IGL) takes about 35 to $40 \mathrm{hr}$ in the mouse (Fujita et al., 1966; Fujita, 1967).

We have designed a microwell tissue culture system of early postnatal mouse cerebellum to analyze cell movements and cell interactions (Trenkner and Sidman, 1977). Within hours after being placed in culture cerebellar cells form reaggregates which later develop interconnections consisting of bundles of cell processes, here referred to as cables. Presumptive granule cells migrate along the cables (Trenkner and Sidman, 1977). This in vitro system allows for the analysis of the dynamics of cell behavior important to histogenesis.

The aim of this study is to analyze the timed sequence of granule cell maturation and to determine whether this sequence is intrinsic to granule cells or dependent upon environmental signals.

\section{Materials and Methods}

Microwell tissue culture. Single cell suspensions of early postnatal mouse cerebellum (C57BL/6J) were prepared as described earlier (Trenkner and Sidman, 1977). Cells $\left(5 \times 10^{4}\right)$ of 3 -day-old mice were cultured in microtiter plates (Falcon 3034) for 3 and 6 days, respectively. Cells were maintained in Eagle's basal medium supplemented with $10 \%$ horse serum, glutamine, penicillin, and streptomycin as detailed elsewhere ('Trenkner and Sidman, 1977).

Time lapse cinematography. Migratory behavior of granule cells was monitored in vitro over a period of 6 days by time lapse cinematography as described previously (Trenkner and Sidman, 1977). 
Thymidine label. Three- to 7-day-old (P3 to $\mathrm{P} 7) \mathrm{C} 57 \mathrm{BL} / 6 \mathrm{~J}$ mice were immobilized on ice and injected subcutaneously with $5 \mu \mathrm{l}$ of $\left[{ }^{3} \mathrm{H}\right]$ thymidine $\left(\left[{ }^{3} \mathrm{H}\right] \mathrm{Thy}\right)(25 \mathrm{Ci} / \mathrm{mmol}$, Amersham Searle). At given times after label, cultures were fixed in $4 \%$ paraformaldehyde in phosphatebuffered saline (PBS) ( $\mathrm{pH} \mathrm{7.4)}$ ) and $0.25 \%$ glutaraldehyde, washed three times in PBS, and dehydrated in ethanol. To determine the number of labeled cells in single cell preparation, cells were centrifuged and the pellet was fixed, dehydrated, and embedded as described before. If necessary, cells were pelleted after each step by centrifugation (1000 $\mathrm{rpm})$. Subsequently, cultures were subjected to autoradiography.

Autoradiography. Approximately $3 \mu \mathrm{l}$ of a 1:3 dilution of Ilford G-5 emulsion were added per microwell, dried, and exposed for 4 weeks at $-70^{\circ} \mathrm{C}$. Cultures were counterstained with $1 \%$ toluidine blue, and the number of labeled versus unlabeled cells on cables was determined. To determine the distribution of labeled cells in reaggregates, cultures of $\left[{ }^{3} \mathrm{H}\right] \mathrm{Thy}-\mathrm{labeled}$ cells were fixed, dehydrated and embedded in Epon as described previously (Trenkner and Sidman, 1977). One-micrometer sections were coated with a 1:2 dilution of Ilford G-5 and exposed for 6 weeks at $-70^{\circ} \mathrm{C}$. Sections were counterstained with toluidine blue.

Scanning electron microscopy. After fixation and dehydration in ethanol, cultures were critical point dried with liquid $\mathrm{CO}_{2}$ and coated with carbon and gold palladium (Boyde et al., 1977).

\section{Results}

Behavior of migrating cells in vitro. In earlier work cell migration was studied by time lapse cinematography in a microwell tissue culture system (Trenkner and Sidman, 1977). Morphological characterization of migrating cells suggested that these cells are granule cell neurons (Trenkner and Sidman, 1977). In this study we attempted to relate cell shape to migrating behavior in order to distinguish migrating cells from non-migrating cells in fixed cultures.

The state of motion of 500 migrating cells was analyzed in time lapse movies over a period of 5 days and grouped into three categories: "running," "intermediate," and "standing." One typical example of a cable with all three types visible on it is illustrated in Figure 1. The presumptive granule cell neurons migrate along cables consisting of parallel fiber fascicles and glial processes (Liem et al., 1982). The speed of migration of individual cells varies considerably between 0.5 and $25 \mu \mathrm{m} / \mathrm{hr}$. Occasionally they change directions, in certain cases up to four times, and rotate around the cable.

The shape of a cell is related to its state of motion. Running (r) cells (10 to $25 \mu \mathrm{m} / \mathrm{hr}$ ) were stretched along the cable and had a drop-like shape, with the thinner pole pointing toward the direction of migration (Fig. 1$)$. Intermediate (i) cells ( 0.5 to $5 \mu / 1)$ were rounder but remain attached to the cable over the length of their cell body (5 to $6 \mu \mathrm{m}$ ) (Fig. 1). Migrating cells pass each other and non-migrating cells, apparently uninfluenced by them. The number of migrating cells was approximately the same throughout the culture period of 6 days. This indicates that the decline of migratory activity of particular granule cell generations does not reflect a change in culture conditions.

There are also cells which are permanently postmigratory. We call these "standing" cells. They are round, barely attached to cables, and clustered together. This might suggest that the surface properties of granule cells differ with the migratory state (Fig. 1). Postmigratory (standing) cells were never seen to resume migration.

Migrating cerebellar cells in vitro are granule cells. The vast majority of cells $(95 \%)$ dividing postnatally in the cerebellum are external granule cells (Miale and Sidman, 1961; Fujita, 1964, 1967; Fujita et al., 1966; Altman, 1982). Therefore, $\left[{ }^{3} \mathrm{H}\right]$ Thy provides a useful marker to follow the development of particular granule cell generations. We define a generation of granule cells as those cells which enter the postmitotic state at the same time.

P3 mice were injected subcutaneously with $\left[{ }^{3} \mathrm{H}\right] \mathrm{Thy}$ once. Twenty-three to $28 \%$ of EGCs and 9 to $12 \%$ of cells in the IGL were labeled $4 \mathrm{hr}$ after injection. No cells in the molecular layer (ML) were labeled at this time. Comparable numbers of labeled cells (23 to $26 \%$ ) were observed in freshly prepared single cell suspensions, as determined in $1-\mu \mathrm{m}$ sections of the cell pellet.

After 2 to 3 days in culture a considerable number of $\left[{ }^{3} \mathrm{H}\right]$ Thy-labeled cells appeared on cables as demonstrated in Fig-

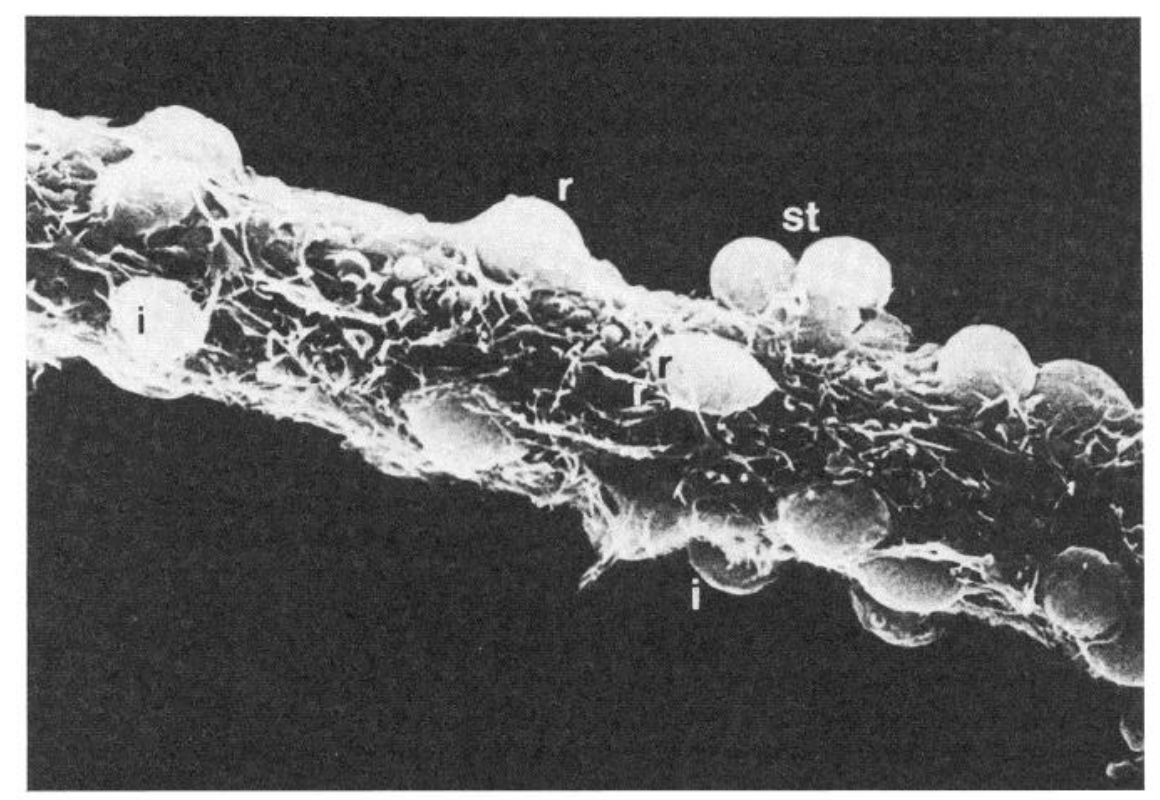

Figure 1. Scanning electron micrograph of migrating granule cells on a "cable." The shapes of the cells reflect their migrating activity. $r$, Running or fast moving cells (10 to 25 $\mu \mathrm{m} / \mathrm{hr}$ ) were stretched along the cable. $i$, Intermediate or slow moving cells ( 0.5 to $5 \mu \mathrm{m} /$ $\mathrm{hr}$ ) were rounded up but remained attached to the cable over the length of their cell body. $s t$, Standing cells did not migrate and have never been observed to migrate again. They rounded up barely attached to the cable and formed contacts between each other. Magnification $\times 2000$. 
ures 2 and 3 . Since in vivo nearly all labeled cells are granule cells, this, taken together with results from earlier studies (Trenkner and Sidman, 1977) suggests that migrating cells in the microwell tissue culture system are granule cells.

Timing of the sequence of granule cell maturation in vitro. To determine whether granule cells maintain their developmental schedule under tissue culture conditions the development of granule cells was analyzed in vitro and the timing of the sequence of developmental changes was compared with that of granule cells in vivo. EGCs were labeled at P3 and put into culture $4 \mathrm{hr}$ later. Cultures were maintained for 7 days, and the number of labeled cells on cables and in reaggregates was determined by autoradiography at daily intervals (Figs. 3 and $5 B)$.

In vivo, 35 to $40 \mathrm{hr}$ after injection the labeled granule cells increase in number in the molecular layer (ML), and after 48 to $52 \mathrm{hr}$ they reach the IGL (Fujita, 1967; E. Trenkner, unpublished observation). After 2 days in vitro approximately $26 \%$ of cells migrating on cables were labeled. This increased to 35 to $37 \%$ after 3 days in vitro. The greatest percentage of labeled cells is found on cables after 72 to $96 \mathrm{hr}$, since the fraction gradually decreases after $96 \mathrm{hr}$ in culture. After 6 days, when more than 95 to $98 \%$ of all labeled granule cells in vivo are found in the IGL, only 8 to $14 \%$ of the labeled cells in vitro were found on cables. They were mostly in a standing state or aggregated on the cables. On the other hand, unlabeled cells continued to migrate, indicating that the conditions for migration were maintained throughout the period of culture.

The percentage of labeled cells in reaggregates was determined in $1-\mu \mathrm{m}$ sections. Twenty-six to $30 \%$ of the granule cells were labeled after 2 days in vitro. Most of them were scattered

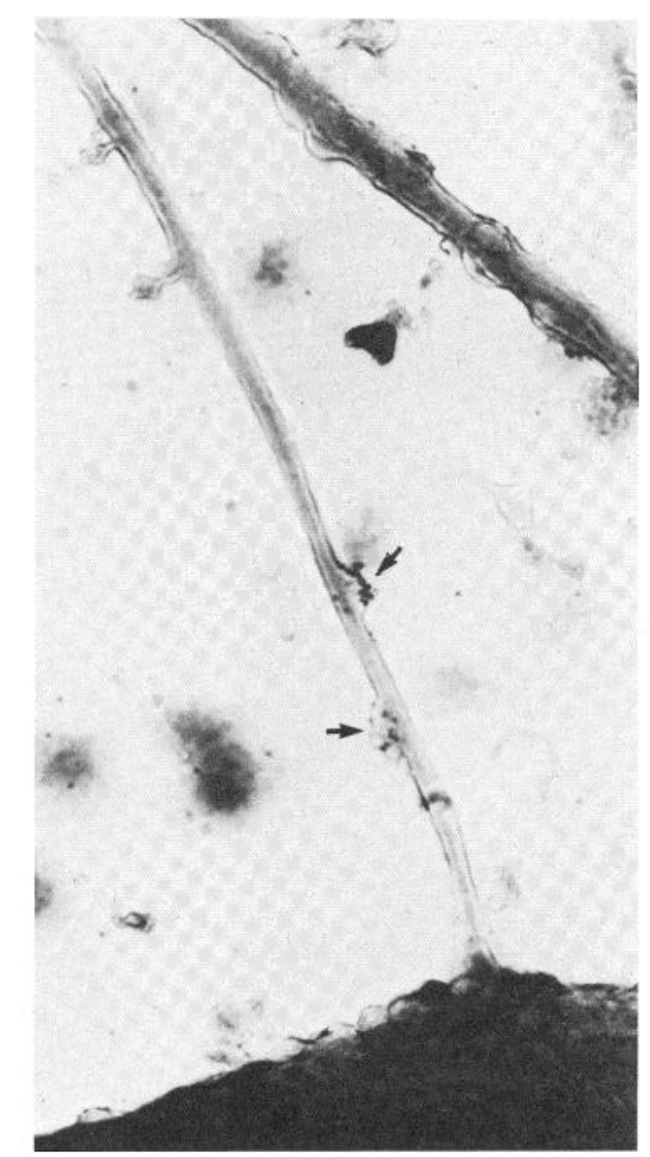

Figure 2. Autoradiogram of migrating granule cells (arrows) on cables which were labeled with $\left[{ }^{3} \mathrm{H}\right]$ Thy prior to culturing. throughout the reaggregate (Fig. $3 A$ ). With time in culture the percentage of labeled granule cells in reaggregates decreased to approximately $14 \%$, at a time when the majority of labeled granule cells migrated on the cables. However, after 5 to 6 days in vitro, the percentage of labeled granule cells in reaggregates increased again to approximately 23 to $28 \%$. These cells were associated with other granule cells in clusters similar to those described in the IGL (Fig. $3 C$ ).

As described above, migrating cells change their shape according to their activity. Figure 4 represents the distribution of labeled cells (one or two generations of granule cells) into the three categories defined above, as was determined over a period of 6 days in culture. After 2 days in vitro the majority ( $\sim 60$ to $80 \%$ ) were in the running and intermediate state, whereas less than $10 \%$ fell into the category of standing cells. This proportion changed with increasing time in culture: whereas the percentage of running cells decreased, the percentage of standing cells increased until after 6 days in vitro when more than $60 \%$ of all labeled cells became postmigratory in vivo.

The evidence described above indicates that the timed sequence which regulates granule cell development is intrinsic to the granule cell.

Timed sequence of granule cell maturation in vitro reflects developmental state of granule cells in vivo. The results described above suggest that granule cells of a particular generation maintain their ability to migrate in vitro even 2 days after having entered the IGL in vivo. To demonstrate this, experiments have been designed to allow granule cell development in vivo and, at particular times, determine their state of maturation in vitro.

Mice were injected once with $\left[{ }^{3} \mathrm{H}\right] \mathrm{Thy}$ and maintained up to 6 days with their mother. Cerebellar cells were prepared for culture at 1 to 6 days after label and cultured for 3 days, and the percentage of labeled cells on cables was determined autoradiographically. The results are documented in Figure $5 \mathrm{~A}$. Five to $22 \%$ of cells on cables were labeled when prepared from mice which were injected with $\left[{ }^{3} \mathrm{H}\right]$ Thy 1 day before culturing. This number increased to 32 to $43 \%$ when cultures were prepared from mice labeled 3 or 4 days before culturing. On the other hand, the percentage of labeled cells from mice injected with $\left[{ }^{3} \mathrm{H}\right]$ Thy 5 to 6 days before culturing was reduced considerably to about 12 to $18 \%$ and 9 to $12 \%$, respectively. The total number of cells remained constant throughout the culture period. These results support the evidence described above that granule cells maintain their ability to migrate for about 2 days after reaching the IGL in vivo.

It appears unlikely that the increase of labeled cells on cables or in reaggregates is due to cell division in vitro. When P3 cerebellar cells were cultured and pulse labeled for $3 \mathrm{hr}$ with $\left[{ }^{3} \mathrm{H}\right]$ Thy at various times in vitro, neither thymidine incorporation nor mitotic figures were observed in granule cell populations after $24 \mathrm{hr}$ in vitro (not shown). Furthermore, the position and interaction of labeled cells in reaggregates and on cables indicate distinct stages of maturation. The results also indicate that reaggregates and cables provide the appropriate environment for particular stages in granule cell development.

\section{Discussion}

The experiments described are designed, first, to illustrate that the migrating cells on cables are granule cells and, second, to elucidate the time frame in which granule cells mature.

The time of origin and route of migration of immature granule cell neurons have been described in numerous studies (Miale and Sidman, 1961; Fujita, 1964, 1967; Fujita et al., 1966; Altman, 1982). Miale and Sidman (1961) showed that granule cells originate at the rhombic lip, spread as a thin layer across the external surface of the developing cerebellar anlage, and proliferate postnatally. Details on the timing of granule cell 

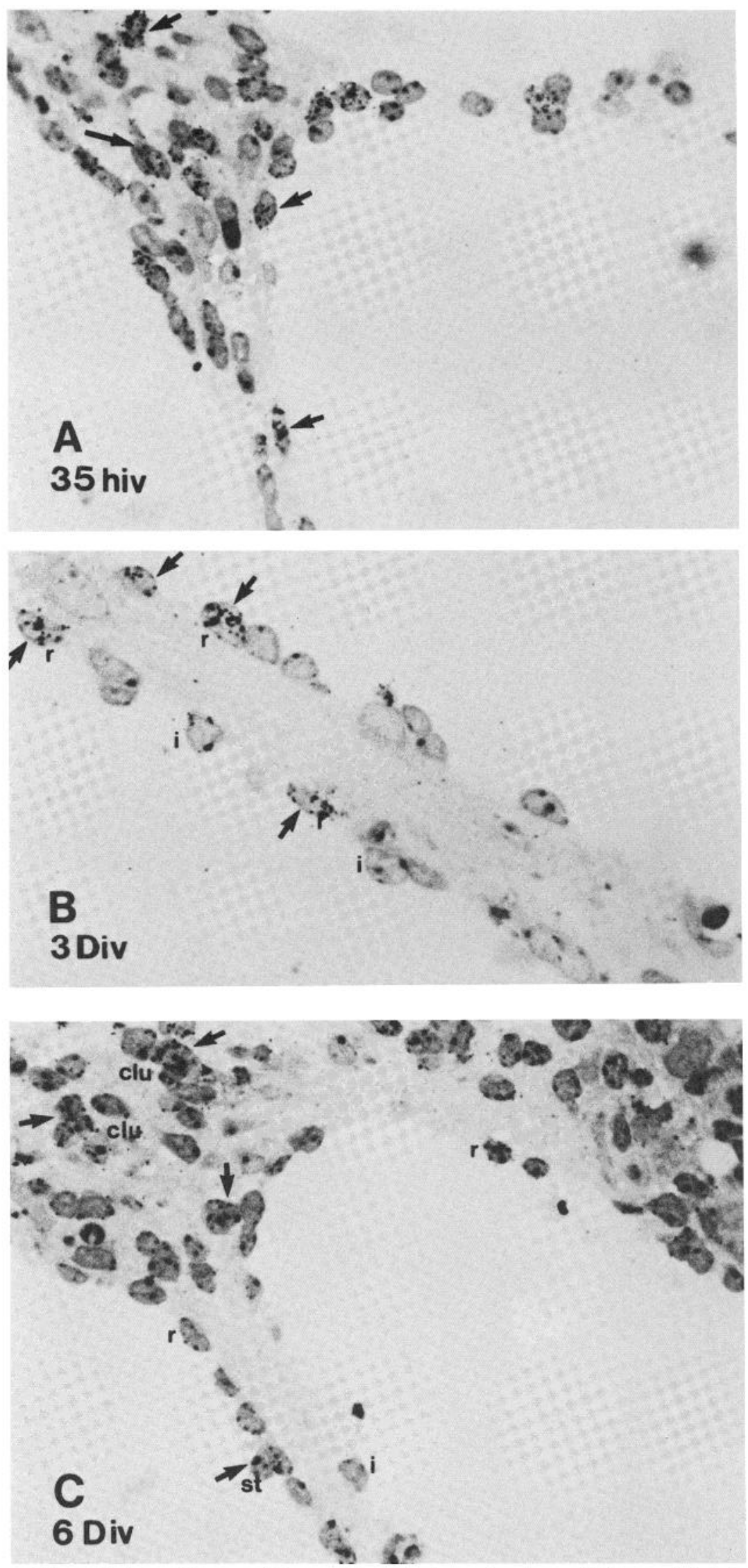

Figure 3. Autoradiogram of 1- $\mu \mathrm{m}$ sectioned microwell cultures. Cells were labeled with $\left[{ }^{3} \mathrm{H}\right]$ Thy $4 \mathrm{hr}$ before culturing. After $35 \mathrm{hr}$ in vitro (hiv) $(A)$, and $3(B)$ and 6 (C) days in vitro (Div) cultures were fixed in $4 \%$ paraformaldehyde, embedded in Epon, and thin sectioned. $r$, running cells; $i$, intermediate cells; st, standing cells; $c l u$, cluster of granule cells. Examples of labeled cells are marked with an arrow. 


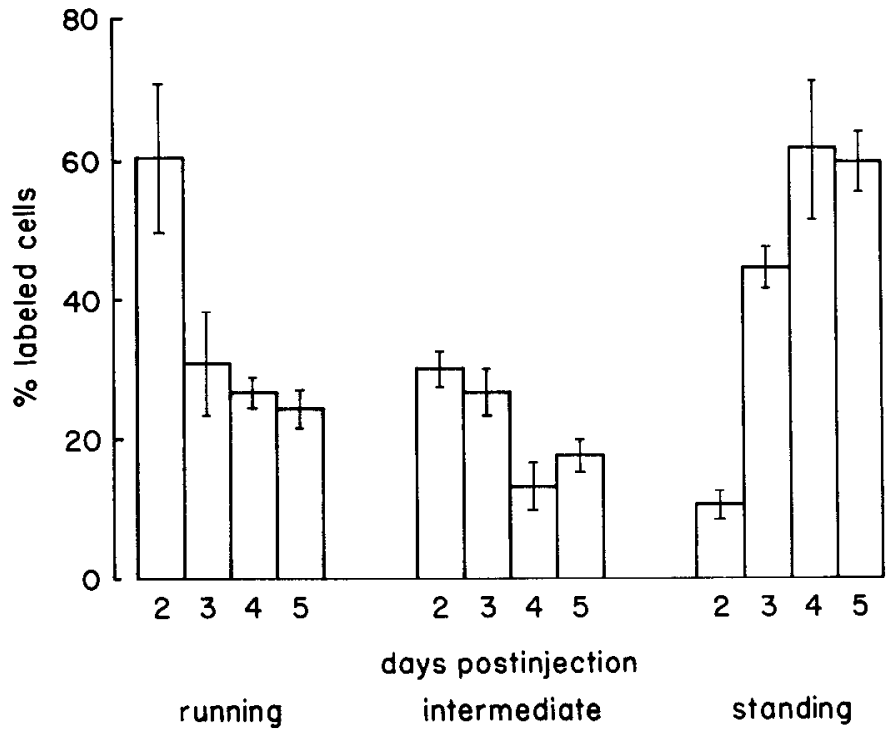

Figure 4. Distribution of $\left[{ }^{3} \mathrm{H}\right]$ Thy-labeled cells among the three categories of migratory behavior (running, intermediate, and standing) after 2 to 5 days in vitro. A total number of 1500 cells was scored in six experiments, and the percentage of labeled to total granule cells was determined. The error bars represent the variation of the percentage of labeled to total cells in six experiments.

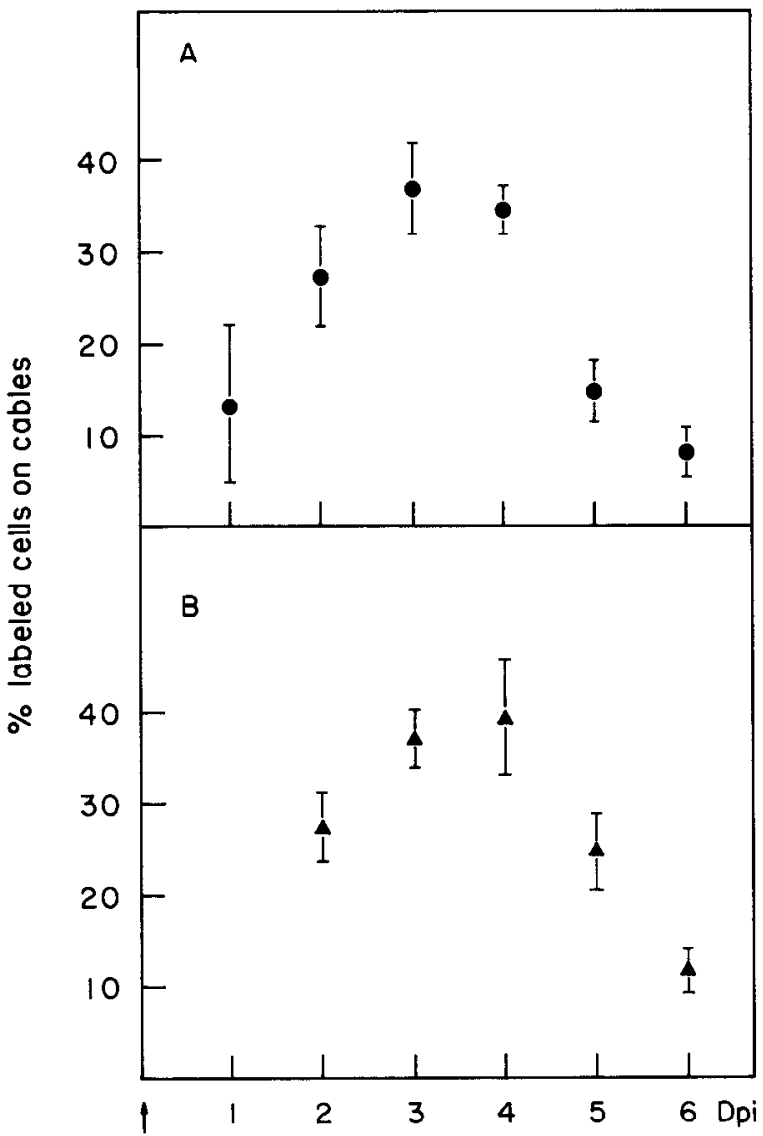

Figure 5. Number of labeled granule cells on cables (expressed as percentage of labeled to total cells). $A, \mathrm{P} 3$ mice were injected once with $\left.{ }^{3} \mathrm{H}\right] \mathrm{Thy}$. In intervals of 1 to 6 days postinjection ( 1 to $6 \mathrm{Dpi}$ ) cerebellar cells were cultured for 3 days and the percentage of labeled cells was determined autoradiographically in six experiments. $B, \mathrm{P} 3$ mice were injected once with $\left[{ }^{3} \mathrm{H}\right]$ Thy and after $4 \mathrm{hr}$ were cultured for 6 days. In daily intervals the percentage of labeled cells was determined autoradiographically. The data were obtained from nine experiments. There were 1500 cells scored in $A$ and $B$, respectively. The error bars demonstrate the variation of percentage of labeled cells in six experiments. proliferation have been provided by the studies of Fujita in the mouse (Fujita, 1964, 1967; Fujita et al., 1966) and Altman for the rat (Altman, 1982). During the initial period of proliferation, all FGCs seem to be engaged in DNA synthesis and mitosis. Immediately after the $\mathrm{S}$ phase, $\left[{ }^{3} \mathrm{H}\right]$ Thy-labeled cells move from a superficial position to occupy a postmitotic zone at the inner face of the EGL. In the mouse, labeled cells appear to wait in the postmitotic zone for 21 to $24 \mathrm{hr}$ and then migrate into the deeper layers of the cortex. Other cells continue to transit the cell cycle and, after their final mitosis, seem to follow the same sequence to migrate into the IGL. According to Fujita et al. (1966), granule cells take less than $5 \mathrm{hr}$ to migrate through the $\mathrm{ML}$ and are subsequently distributed throughout the IGL. The time frame which is required for granule cells to reach their final destination in the IGL is not yet known.

The results reported here suggest that the maturation of granule cells in vitro is comparable to that in vivo; pulse-labeled granule cells behaved in vitro as their in vivo counterparts did.

However, in vitro, the time frame of migration of granule cells appears to be prolonged. When cells were cultured before or during their migratory state in vivo, the majority of one cell generation labeled with $\left[{ }^{3} \mathrm{H}\right] \mathrm{Thy}$ continued to migrate for 3 to 4 days, which is 2 days longer than required to reach the IGL in vivo (Figs. 4 and 5). When, on the other hand, cells had entered the IGL 3 days before culturing, they did not migrate in vitro. These results suggest, first, that granule cells, once induced to migrate, maintain the ability to do so for 3 to 4 days before they either home in reaggregates or form clusters with other granule cells on cables. The results also suggest that granule cells might change their cell surface properties after their period of migration and that such changes are required in their forming clusters (Figs. 3 and 4). This behavior is not due to a change in culture conditions since unlabeled cells continue to migrate throughout the culture period.

Although the overall correlation of the time frame of granule cell maturation in vivo and in vitro reported here suggests that granule cell maturation is controlled intrinsically, certain extrinsic factors have to be considered. If cells are trypsinzed before culturing, 6 to $12 \mathrm{hr}$ are required to rebuild their cell surface (E. Trenkner, unpublished observation). That is, under these conditions, cables are formed and cells can begin to migrate only after 28 to $30 \mathrm{hr}$ in culture. Therefore, it is possible that this delay, built into the culture system, might be the explanation for the prolonged migration time in vitro as compared to in vivo. On the other hand, this delay did not affect cells which entered the IGL 3 days before culturing. In addition, the time sequence of granule cells which developed in vivo and were assayed in vitro, and that of granule cells developed in vitro, appeared to be the same.

In conclusion, we would like to postulate that the duration of granule cell migration in the cerebellum is controlled intrinsically. Secondly, the results suggest that granule cells continue to migrate after entering the IGL for a predetermined time unless they receive an external signal to stop.

\section{References}

Altman, J. (1982) Morphological development of the rat cerebellum and source of its mechanisms. Exp. Brain Res. Suppl. 6: 8-49.

Boyde, A., E. Bailey, S. J. Jones, and A. Tamarin (1977) Dimensional changes during specimen preparation for SEM. Scanning Electron Microsc. 1: 507-518.

Caviness, V., and P. Rakic (1978) Mechanisms of cortical development: A view from mutations in mice. Annu. Rev. Neurosci. 1: 297-326.

Fujita, S. (1964) Analysis of neuron differentiation in the central nervous system by tritiated thymidine autoradiography. J. Comp. Neurol. 122: 311-328.

Fujita, S. (1967) Quantitative analysis of cell proliferation and differentiation in the cortex of the postnatal mouse cerebellum. J. Cell Biol. 32: 277-287. 
Fujita, S., M. Shimada, and T. Nakamura (1966) ${ }^{3} \mathrm{H}$-Thymidine autoradiographic studies on the cell proliferation and differentiation in the external and the internal granule cell layer of the mouse cerebellum. J. Comp. Neurol. 128: 191-208.

Levitt, P., and P. Rakic (1980) Immunoperoxidase localization of glial fibrillary acidic protein in radial glial cells and astrocytes of the developing rhesus monkey brain. J. Comp. Neurol. 193: 815-840.

Liem, R. K. H., C. H. Keith, J. F. Leterrier, E. Trenkner, and M. L. Shelanski (1982) Chemistry and biology of neuronal and glial intermediate filament. Cold Spring Harbor Symp. Quant. Biol. 46: 341350.

Miale, I. R., and R. L. Sidman (1961) An autoradiographic analysis of histogenesis in the mouse cerebellum. Exp. Neurol. 4: 277-296.

Rakic, P. (1971) Neuron-glia relationship during granule cell migration in developing cerebellar cortex. A Golgi and electron microscopic study in Macacus rhesus. J. Comp. Neurol. 141: 283-312.

Rakic, P. (1974) Intrinsic and extrinsic factors influencing the shape of neurons and their assembly into neural circuits. In: Frontiers on Neurology and Neurosciences Research, P. Seeman and G. M. Brown, eds., p. 112, University of Toronto Press, Toronto.

Rakic, P. (1978) Neuronal migration and contact guidance in the primate telencephalon. Postgrad. Med. J. 54: 25-40.

Rakic, P. (1981) Neuronal-glial interaction during brain development. Trends Neurosci. 4: 184-187.

Ramón y Cajal, S. (1929) Studies in Vertebrate Neurogenesis, L. Guth, transl. (1960), Charles C Thomas, Springfield, IL.

Trenkner, F., and R. L. Sidman (1977) Histogenesis of mouse cerebellum in microwell cultures. J. Cell Biol. 75: 915-940. 